\title{
Residential Energy Consumption across Different Population Groups: Comparative Analysis for Latino and Non-Latino Households in U.S.A.
}

\author{
RERTER \\ AUG 101998 \\ OSTI
}

Decision and Information Sciences Division

Argonne National Laboratory

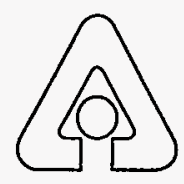

Operated by The University of Chicago, under Contract W-31-109-Eng-38, for the United States Department of Energy 


\section{Argonne National Laboratory}

Argonne National Laboratory, with facilities in the states of Illinois and Idaho, is owned by the United States Government, and operated by the University of Chicago under the provisions of a contract with the Department of Energy.

This technical memo is a product of Argonne's Decision and Information Sciences (DIS) Division. For information on the division's scientific and engineering activities, contact:

Director, Decision and Information Sciences Division

Argonne National Laboratory

Argonne, Illinois 60439-4832

Telephone (630) 252-5464

http://www.dis.anl.gov

Presented in this technical memo are preliminary results of ongoing work or work that is more limited in scope and depth than that described in formal reports issued by the DIS Division.

Publishing support services were provided by Argonne's Information and Publishing Division (for more information, see IPD's home page: http://www.ipd.anl.gov/)

\section{Disclaimer}

This report was prepared as an account of work sponsored by an agency of the United States Government. Neither the United States Government nor any agency thereof, nor any of their employees, makes any warranty, express or implied, or assumes any legal liability or responsibility for the accuracy, completeness, or usefulness of any information, apparatus, product, or process disclosed, or represents that its use would not infringe privately owned rights. Reference herein to any specific commercial product, process, or service by trade name, trademark; manufacturer, or otherwise, does not necessarily constitute or imply its endorsement, recommendation, or favoring by the United States Government or any agency thereof. The views and opinions of authors expressed herein do not necessarily state or reflect those of the United States Government or any agency thereof.

Reproduced directly from the best available copy.

Available to DOE and DOE contractors from the Office of Scientific and Technical Information, P.O. Box 62, Oak Ridge, TN 37831; prices available from (423) 576-8401.

Available to the public from the National Technical Information Senvice, U.S. Department of Commerce, 5285 Port Royal Road, Springfield, VA 22161. 


\section{Residential Energy Consumption across Different Population Groups: Comparative Analysis for Latino and Non-Latino Households in U.S.A.}

by D.A. Poyer, L. Henderson, ${ }^{*}$ and A.P.S. Teotia*

Decision and Information Sciences Division,

Argonne National Laboratory, 9700 South Cass Avenue, Argonne, Illinois 60439

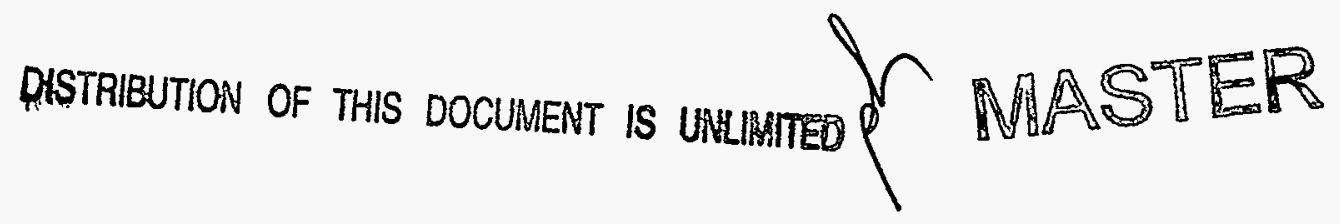

May 1998

Work sponsored by U.S. Department of Energy, Office of Economic Impact and Diversity

* Henderson is affiliated with the University of Baltimore; Teotia is affiliated with Argonne's Energy Systems Division. 


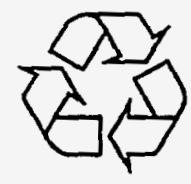

This report is printed on recycled paper.

ii 


\section{DISCLAIMER}

Portions of this document may be illegible electronic image products. Images are produced from the best available original document. 


\section{PREFACE}

This Argonne National Laboratory report is a product of extensive analytical and data base capabilities developed while conducting research sponsored by the U.S. Department of Energy's Office of Economic Impact and Diversity for over 10 years. These capabilities were used in estimating the dynamic energy demand models for black, non-black, Latino, and nonLatino households described in this report. This report is, for the most part, a reprint of research published in Energy Economics (19 [1997] 445-463). 


\section{CONTENTS}

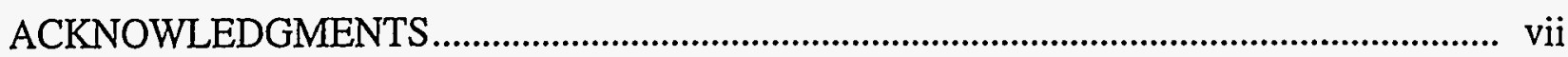

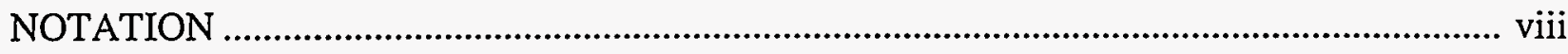

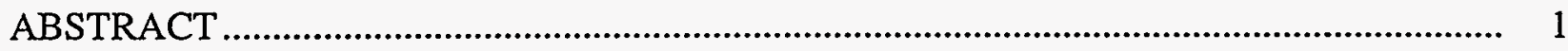

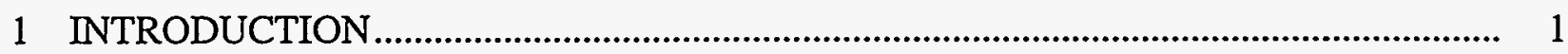

2 EFFECTS OF SOCIOECONOMIC AND CULTURAL/BEHAVIORAL

FACTORS ON ENERGY CONSUMPTION ......................................................................... 3

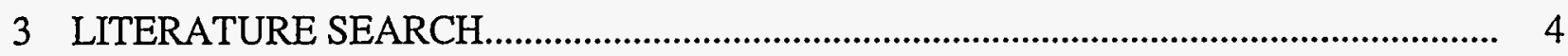

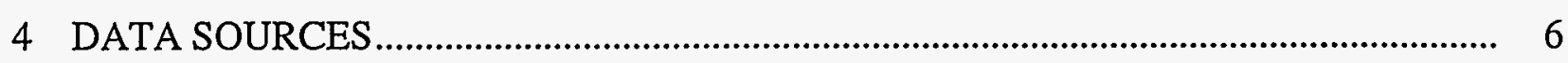

5 PROPOSED HOUSEHOLD ENERGY DEMAND

AND EXPENDITURE MODEL .................................................................................. 7

6 EMPIRICAL ANALYSIS OF DATA GENERATED

FROM APPLICATION OF THE MODEL ....................................................................... 10

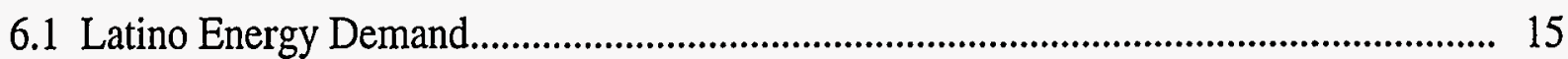

6.2 Black Energy Demand........................................................................................... 19

7 POLICY IMPLICATIONS OF DIFFERENCES IN LATINO

AND NON-LATINO ENERGY DEMAND …..................................................................... 21

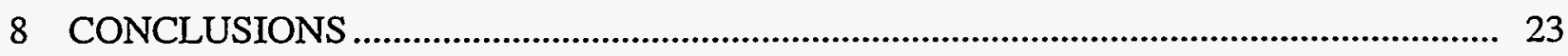

REFERENCES

\section{FIGURES}

11990 Composition of Fuel Use: Non-Latino White Households ....................................... 12

21990 Composition of Fuel Use: Latino Households ........................................................ 13

31990 Composition of Fuel Use: Non-Latino Black Households.............................................. 14 


\section{TABLES}

1 Total Energy and Electricity Expenditures.......................................................... 11

2 Dynamic Energy Demand Model Estimates: Latino and Non-Latino Households.............. 16

3 Dynamic Energy Demand Model Estimates: Black and Non-Black Households ................ 17

4 Energy Expenditure Model Estimates: Latino and Non-Latino Households ...................... 18

5 Energy Expenditure Model Estimates: Black and Non-Black Households ........................ 20 


\section{ACKNOWLEDGMENTS}

This report was developed under the sponsorship of the U.S. Department of Energy, Office of Economic Impact and Diversity, under Contract W-31-109-Eng-38. Special appreciation is extended to Georgia R. Johnson, Assistant Director for Research and Technology Enterprises Development, Office of Economic Impact and Diversity, whose support over many years has led to this publication. The authors also thank Mary Fitzpatrick for editing of this report. This report documents the results of research conducted by the authors; any opinions expressed herein are theirs alone. 


\section{NOTATION}

$\begin{array}{ll}\text { CDD } & \text { cooling degree days } \\ \text { DOE } & \text { U.S. Department of Energy } \\ \text { EIA } & \text { Energy Information Administration } \\ \text { HDD } & \text { heating degree days } \\ \text { LIHEAP } & \text { Low-Income Household Energy Assistance Program } \\ \text { LPG } & \text { liquefied petroleum gas } \\ \text { RECS } & \text { Residential Energy Consumption Survey }\end{array}$




\title{
RESIDENTIAL ENERGY CONSUMPTION ACROSS DIFFERENT POPULATION GROUPS: COMPARATIVE ANALYSIS FOR LATINO AND NON-LATINO HOUSEHOLDS IN U.S.A.
}

by

\author{
D.A. Poyer, L. Henderson, and A.P.S. Teotia
}

\begin{abstract}
Residential energy cost, an important part of the household budget, varies significantly across different population groups. In the United States, researchers have conducted many studies of household fuel consumption by fuel type electricity, natural gas, fuel oil, and liquefied petroleum gas (LPG) - and by geographic areas. The results of past research have also demonstrated significant variation in residential energy use across various population groups, including white, black; and Latino. However, our research shows that residential energy demand by fuel type for Latinos, the fastest-growing population group in the United States, has not been explained by economic and noneconomic factors in any available statistical model. This paper presents a discussion of energy demand and expenditure patterns for Latino and non-Latino households in the United States. The statistical model developed to explain fuel consumption and expenditures for Latino households is based on Stone and Geary's linear expenditure system model. For comparison, we also developed models for energy consumption in non-Latino, black, and nonblack households. These models estimate consumption of and expenditures for electricity, natural gas, fuel oil, and LPG by various households at the national level. The study revealed significant variations in the patterns of fuel consumption for Latinos and non-Latinos. The model methodology and results of this research should be useful to energy policymakers in government and industry, researchers, and academicians who are concerned with economic and energy issues related to various population groups.
\end{abstract}

\section{INTRODUCTION}

Residential energy cost, an important part of the household budget, varies significantly across different population groups in many countries. Energy consumption varies because of differences in such causal factors as fuel prices, climate, housing characteristics (type and age of home), and household characteristics (income, education of the head of the household, and ethnicity/race). In the United States, researchers have conducted many studies to analyze energy consumption by fuel type - including electricity, natural gas, fuel oil, and liquefied petroleum gas (LPG) - and by geographic areas, such as the census regions (DOE 1989b, 1993c). Through its eight Residential Energy Consumption Surveys (RECSs), conducted between 1978 and 1990, 
the U.S. Department of Energy (DOE) Energy Information Administration (EIA) has collected extensive data on energy use by household and related characteristics (DOE 1993c). Each RECS contains data for several thousand households.

Past research has also demonstrated significant variations in residential energy use across various population groups, including white, black, and Latino. For example, the DOE-EIA estimated that the average household energy consumption at the national level in 1987 was $105.7 \times 10^{9} \mathrm{~J}\left(100.2 \times 10^{6} \mathrm{Btu}\right)$ for whites, $116.4 \times 10^{9} \mathrm{~J}$ for blacks, and $92.1 \times 10^{9} \mathrm{~J}$ for Latinos (DOE 1989b). However, our research revealed that residential energy demand by fuel type for Latinos, the fastest-growing population group in the United States, has not been explained by economic and noneconomic factors in any available statistical model.

The purpose of this report is to discuss energy demand and expenditure patterns for Latino and non-Latino households in the United States as a case study of residential energy consumption across different population groups in a country. The statistical model developed to explain fuel consumption and expenditures for Latino households is based on the linear expenditure system model developed by Stone and Geary. For comparison, we also developed models for non-Latino, black, and nonblack households; these models estimate energy consumption of and expenditures for electricity, natural gas, fuel oil, and LPG by various households at the national level. Our study revealed significant variations in the patterns of consumption of these fuels by Latinos and non-Latinos. The model methodology and results of this research should be useful to energy policymakers in government and industry, researchers, and academicians who are concerned with economic and energy issues related to various population groups. 


\section{EFFECTS OF SOCIOECONOMIC AND CULTURAL/BEHAVIORAL FACTORS ON ENERGY CONSUMPTION}

As discussed, past research has revealed significant variation in household energy use across various population groups, including white, black, and Latino. This variation could be attributed to engineering factors (e.g., thermal integrity of home, energy efficiency of appliances), energy factors (e.g., availability and prices of supplied fuels), economic factors (e.g., cost of home and appliances), and household characteristics (e.g., family income, number of household members, race/ethnicity).

The household energy use across white, black, and Latino households in the United States varies because of significant variations in income (generally highest for white and lowest for black), type of homes (proportionately more blacks live in older, less energy-efficient homes and in rental dwellings), urban vs. rural location (blacks concentrate in large urban cities), climate (blacks and Latinos live in more moderate South and West census regions, respectively), and central city location (sometimes restricting availability of natural gas and LPG). Household energy use is also affected by the number of household members; the average black or Latino household is larger than the average white household. The proposed household energy demand model incorporates the effects of these socioeconomic, cultural, and behavioral factors through its explanatory variables. The specification of the model is discussed in the following sections. 


\section{LITERATURE SEARCH}

By using the Social Studies Category Index database for 1992-1994, we conducted a literature search to identify publications on topics related to energy demand by Latino households. We did not identify any publication on energy demand that provided information about household energy consumption, expenditures, or prices by fuel type for Latinos. However, several publications on related topics were reviewed. These characteristics described in the articles (socioeconomic, behavioral) are of interest because of their potential effect on energy consumption patterns in Latino households; the information from these sources is summarized in the following paragraphs.

Chapa and Valencia (1993) discuss Latino population growth and demographic characteristics. Between 1980 and 1990, the Latino population in the United States increased by $53 \%$, while the total population grew by $9 \%$ (U.S. Department of Commerce, Bureau of the Census 1991). About half of this growth was attributable to foreign immigration, and the other half to births in the United States. The Latino population reached more than 22 million in 1990. The authors document that the Latino population has lower income and educational levels, but higher family size, than the non-Latino population.

Perez and Salazar (1993) analyzed the economic implications of the fast-growing Latino population. They characterized the Latino population as undereducated, youthful, and growing. For example, the rate at which Latinos 25 years and older had completed high school in 1989 was only about $51 \%$, compared with $65 \%$ for blacks and $78 \%$ for whites.

Lutzenhiser (1993) reviews literature concerning human factors in energy use, particularly household consumption. According to Lutzenhiser, “... residential-sector consumption seems to be characterized by variability and change, with human behavior playing a central role in both the short- and long-term initiation, maintenance, and alteration of energy flows" (p. 250).

In another article, Lutzenhiser (1992) discussed the value of an emerging cultural or lifestyle model of energy use. The impact of change in lifestyle on energy use is among the issues Lutzenhiser raises. The author states that "The prospects of movement toward a cultural model in energy research seem good." This methodology is exploratory and not directly usable for our research. Nevertheless, it substantiates our approach of estimating household energy consumption by population group, including the Latino population, separately because lifestyles may vary across different groups.

Lee and Singh (1994) analyzed household consumption of electricity and natural gas by using modified regression techniques. One of their objectives was to estimate energy conservation from the perspective of increasing gas availability. Hsing (1994) estimated residential demand for electricity by using the cross-sectionally correlated and time-wise 
autoregressive model. Demand was estimated for five southern U.S. states from 1981-1990. After reviewing these and other commonly used methodologies, we have selected a reliable regression methodology that is more suitable for our objective of estimating energy consumption for Latino households. The lack of a methodology had not been a problem for analyzing energy consumption for Latino households; the lack of data is what has constrained the analysis.

Poyer and Williams (1993) compared total energy and electricity demand elasticities for non-Latino whites with the demand elasticities for Latinos and blacks. This analysis was at the national level, but it did not include other residential fuels (natural gas, fuel oil, and LPG).

Other very good research related to residential energy demand has been done over the past 20 years: see Bohi (1981), Electric Power Research Institute (1982), Blattenberger et al. (1983), Cowing and McFadden (1984), Dubin and McFadden (1984), DOE (1984a), Morrissey (1984), Dubin (1985), Hamblin et al. (1986), Khazzoom (1986), and Baxter et al. (1987). 


\section{DATA SOURCES}

The household energy demand model was developed by using selected data from DOEEIA RECSS conducted for 1980, 1982, 1984, 1987, and 1990 (DOE 1982b, 1985, 1987b, 1989a, 1993a). Several reports on each of these surveys are available (DOE 1982a, 1984b, 1987a, $1989 \mathrm{~b}, 1993 \mathrm{~b}, \mathrm{c})$. The total number of observations in the analyzed data set is 7,823 , out of which 455 observations are for Latino households. The classification as a Latino household was based on self-identification as a Latino by the head of the household in the survey year. A comparison of energy expenditure data for 1981 and 1990 was derived from the 1981 and the 1990 RECSs. A report on the 1981 survey is also available (DOE 1983b). 


\section{PROPOSED HOUSEHOLD ENERGY DEMAND AND EXPENDITURE MODEL}

Given the market, demographic, and policy contexts, we propose a theoretical framework based on the linear expenditure system model developed by Stone (1954) and Geary (19501951). To capture the dynamics of energy demand, Pollak's (1970) dynamic version of the StoneGeary model is used in developing the model.

The Stone-Geary-Pollak utility function is additive and is therefore strongly separable, allowing us to split the utility function by commodity group. For the fuel and energy group, the associated subutility function for the Pollak-Stone-Geary model is as follows:

$$
u_{e}=\prod_{i=1}^{n}\left[q_{i t}-\left(\gamma_{i}+\theta_{i} q_{i(t-1)}\right)\right]^{\beta_{i}}
$$

where $u_{e}$ is the utility index, $q_{i t}$ is the consumption of the $i$ th fuel in period $t, \gamma_{i}$ is the nondiscretionary demand for the $i$ th fuel, $\theta_{i}$ is the dynamic adjustment parameter for the $i$ th fuel, $q_{i(t-1)}$ is the consumption of the $i$ th fuel in period $(t-1)$, and $\beta_{i}$ is the marginal expenditure share on the $i$ th fuel. The model assumes that households maximize Equation 1 subject to total energy expenditures as:

$$
m_{e t}=\sum_{i=1}^{n} p_{i t} q_{i t}
$$

where $m_{e t}$ is the total energy expenditures in period $t$, and $p_{i t}$ is the price of the $i$ th fuel in period $t$. equation:

The maximization of Equation 1 subject to Equation 2 gives the following demand

$$
q_{i t}=\gamma_{i}+\theta_{i} q_{i(t-1)}+\frac{\beta_{i}}{p_{i t}}\left[m_{e t}-\sum_{i=1}^{n} p_{i t}\left(\gamma_{i}+\theta_{i} q_{i(t-1)}\right)\right]
$$

The expenditure counterpart of Equation 3 is

$$
m_{i t}=p_{i t}\left(\gamma_{i}+\theta_{i} q_{i(t-1)}\right)+\beta_{i}\left[m_{e t}-\sum_{i=1}^{n} p_{i t}\left(\gamma_{i}+\theta_{i} q_{i(t-1)}\right)\right]
$$

where $m_{i t}$ is the expenditures on the $i$ th fuel in period $t$.

Energy expenditures can be separated into two component: nondiscretionary and discretionary. The nondiscretionary component is expressed by the first term on the right in Equation 4, and the discretionary component by the second term. Because $\beta_{i}$, must be 
nonnegative and less than unity, an increase in nondiscretionary demand will increase expenditures on the $i$ th fuel. On the contrary, an increase in nondiscretionary demand for fuels other than the $i$ th fuel will lower expenditures on the ith fuel and will also lower its own-price demand elasticity.

Together with the nonnegativity prerequisite, the adding-up condition ${ }^{1}$ requires that the $\beta_{i}$ terms sum to unity. Holding all other things constant, a larger marginal expenditure share implies a larger demand elasticity.

The dynamic adjustment coefficient, which must be between 0 and 1 , measures the extent to which fuel consumption and expenditure change over time in response to changes in either fuel prices or total energy household expenditures. ${ }^{2}$ Larger coefficients are associated with larger long-run demand elasticities. Also, fuel demand equations with a larger dynamic adjustment coefficient imply that a larger fraction of a household's consumption of that fuel is nondiscretionary.

Energy expenditures are assumed to be a linear function of a number of exogenously determined variables, as expressed in this equation:

$$
m_{e t}=\sum_{j=1}^{k} b_{j} x_{j t}
$$

where $b_{j}$ is the coefficient of the $j$ th variable. These variables $\left(x_{j t}\right)$ include household income, number of household members, weather variables, components and changes in the consumer price index, and metropolitan statistical area location. ${ }^{3}$

Within the context of the linear expenditure system, the marginal expenditure share parameter and nondiscretionary demand component are critical in determining how price changes affect expenditures for a particular energy fuel source. In particular, relative expenditures on the $i$ th fuel, in the short run, will be greater the smaller the expenditure share parameter, $\beta_{i}$, and the

1 The adding-up condition requires that the sum of all individual commodity expenditures equal total commodity expenditures, i.e.

$$
m_{e t}=\sum_{i=1}^{n} p_{i t} q_{i t}
$$

2 Demand is homogeneous of degree zero in energy prices and total energy expenditures.

3 In the United States, metropolitan areas with a minimum of 50,000 residents constitute individual Metropolitan Statistical Areas (MSAs). The cost of living in these MSAs varies significantly from location to location on the basis of real estate, labor, and consumer costs. 
larger the nondiscretionary parameter, $\gamma_{i}$, and dynamic adjustment parameter, $\theta_{i}$, with an increase in the price of the $i$ th fuel. In the long run, only the expenditure share and nondiscretionary demand parameters will matter.

The linear expenditure system is associated with an intuitively appealing cost function that provides a rigorous measure of the economic welfare effects of changing prices:

$$
c_{t}=\sum_{i=1}^{n} p_{i t}\left(\gamma_{i}+\theta_{i} q_{i(t-1)}\right)+u \prod_{i=1}^{n} p_{i t}^{\beta_{i}}
$$

where $u$ is the benchmark parameter, which can be interpreted as a measure of utility in some base period. 


\section{EMPIRICAL ANALYSIS OF DATA GENERATED FROM APPLICATION OF THE MODEL}

Table 1 lists total and electricity expenditures (constant 1979 dollars) for Latino and nonLatino white and black households for 1981 and 1990. The expenditures are broken down by race, Latin ethnicity and poverty status (using household income as an indicator of poverty). Poverty is defined as $125 \%$ of the official U.S. Bureau of the Census poverty figure. These data reveal both similarities and differences in how energy is used and how its use has changed over time for these population groups. In a complex and puzzling way, these data reveal convergence in the total level of expenditures among these groups. However, in some cases, this convergence was accompanied by a divergence in energy expenditure patterns by population group and by variations in rates of change in fuel-type expenditures by poverty status.

In general, energy expenditures for non-Latino whites and blacks were about the same, but the composition of those expenditures was different. Typically, non-Latino whites spent relatively more on electricity, even though a larger fraction of the black population lives in the south, where electricity is more extensively used. On the other hand, Latino households spent substantially less on energy than non-Latino whites, but the relative expenditures for electricity were about the same for both groups.

In both periods (i.e., 1981, 1990), electricity expenditures for non-Latino white households were larger than those for Latino and non-Latino black households. As mentioned, total energy expenditures by non-Latino white and black households were virtually the same for the period; however, expenditures declined at a faster rate for non-Latino blacks. The faster decline in energy expenditures by black households was mostly caused by a dramatic decline in total expenditures by nonpoor blacks. Together with the convergence in overall energy expenditures, the composition of energy expenditures between non-Latino white and black households became more similar, with the share of expenditures for electricity rising faster for black households.

For Latino households, the decline in total energy expenditures was not as large as for non-Latino whites. Unlike for non-Latino blacks, the decline in energy expenditure by nonpoor Latinos was relatively small. For both poor and nonpoor Latinos, electricity expenditures increased between 1981 and 1990. As in the case of non-Latinos, the share of expenditures for electricity increased dramatically for Latinos between 1981 and 1990.

Figures 1 through 3 show the relative importance of various residential energy sources by population group and region (DOE 1993a). In these figures, energy consumption fractions are shown for five residential energy sources: natural gas, electricity, LPG, fuel oil, and kerosene. 
TABLE 1 Total Energy and Electricity Expenditures (constant 1979\$/household)

\begin{tabular}{|c|c|c|c|c|c|c|}
\hline \multirow[b]{2}{*}{ Household } & \multicolumn{2}{|c|}{$1981^{a}$} & \multicolumn{2}{|c|}{$1990^{a}$} & \multicolumn{2}{|c|}{ Change (\%) } \\
\hline & Electricity & Total & Electricity & Total & Electricity & Total \\
\hline \multicolumn{7}{|c|}{ Non-Latino white } \\
\hline Non-poor & $\begin{array}{r}470 \\
(8)\end{array}$ & $\begin{array}{l}852 \\
(13)\end{array}$ & $\begin{array}{c}459 \\
(7)\end{array}$ & $\begin{array}{l}697 \\
(10)\end{array}$ & -2.3 & -18.2 \\
\hline Poor & $\begin{array}{l}352 \\
(12)\end{array}$ & $\begin{array}{l}667 \\
(19)\end{array}$ & $\begin{array}{l}341 \\
(13)\end{array}$ & $\begin{array}{l}537 \\
(17)\end{array}$ & -3.1 & -19.5 \\
\hline Total & $\begin{array}{r}452 \\
(7)\end{array}$ & $\begin{array}{l}824 \\
(12)\end{array}$ & $\begin{array}{r}440 \\
(6)\end{array}$ & $\begin{array}{c}672 \\
(9)\end{array}$ & -2.7 & -18.4 \\
\hline \multicolumn{7}{|c|}{ Non-Latino black } \\
\hline Non-poor & $\begin{array}{l}446 \\
(21)\end{array}$ & $\begin{array}{l}940 \\
(35)\end{array}$ & $\begin{array}{l}417 \\
(21)\end{array}$ & $\begin{array}{l}692 \\
(29)\end{array}$ & -6.5 & -26.4 \\
\hline Poor & $\begin{array}{l}339 \\
(18)\end{array}$ & $\begin{array}{l}724 \\
(30)\end{array}$ & $\begin{array}{c}332 \\
(22)\end{array}$ & $\begin{array}{l}595 \\
(32)\end{array}$ & -2.1 & -17.8 \\
\hline Total & $\begin{array}{l}400 \\
(15)\end{array}$ & $\begin{array}{l}848 \\
(26)\end{array}$ & $\begin{array}{l}385 \\
(15)\end{array}$ & $\begin{array}{l}656 \\
(22)\end{array}$ & -3.8 & -22.6 \\
\hline \multicolumn{7}{|l|}{ Latino } \\
\hline Non-poor & $\begin{array}{c}398 \\
(22)\end{array}$ & $\begin{array}{l}727 \\
(32)\end{array}$ & $\begin{array}{l}437 \\
(27)\end{array}$ & $\begin{array}{l}628 \\
(32)\end{array}$ & 9.8 & -13.6 \\
\hline Poor & $\begin{array}{l}260 \\
(22)\end{array}$ & $\begin{array}{l}604 \\
(38)\end{array}$ & $\begin{array}{l}283 \\
(27)\end{array}$ & $\begin{array}{l}472 \\
(35)\end{array}$ & 8.8 & -21.9 \\
\hline Total & $\begin{array}{c}361 \\
(18)\end{array}$ & $\begin{array}{c}693 \\
(27) \\
\end{array}$ & $\begin{array}{l}389 \\
(20) \\
\end{array}$ & $\begin{array}{l}580 \\
(25) \\
\end{array}$ & 7.8 & -16.3 \\
\hline
\end{tabular}

a Standard deviations are shown in parentheses.

Source: DOE (1983a, 1993a)=-

The composition of energy consumption is shown by census region 4 and nationally 5 for each population group (Latino and non-Latino black and white) in Figures 1 through 3. Natural gas and electricity are the major energy sources used by all households. However, the regional compositions of natural gas and electricity use vary. Most salient is the large electricity share of total energy consumption in the south census region and the large natural gas share in the Midwest census region.

4 The Southwest is included because of the extraordinary concentration of Latinos in Texas, New Mexico, Arizona, and California.

5 No allowances for electricity production losses are made. Electricity consumption is measured at the point of end use. 


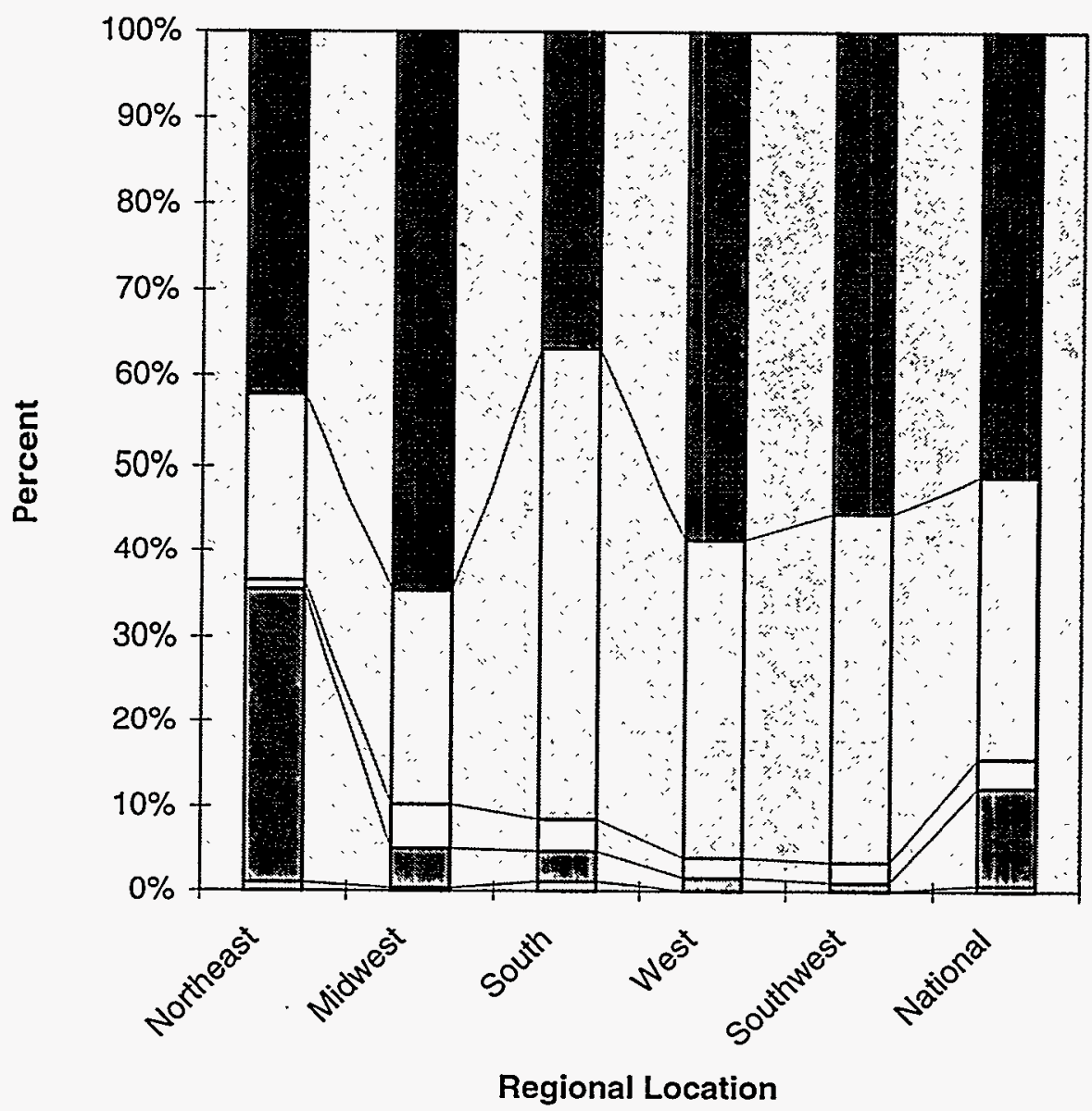

\begin{tabular}{|l|}
\hline Natural Gas \\
口Electricity \\
Liquified Petroleum Gas \\
国Fuel Oil \\
$\square$ Kerosine \\
\hline
\end{tabular}

FIGURE 11990 Composition of Fuel Use: Non-Latino White Households (fuels shown from top to bottom in chart) 


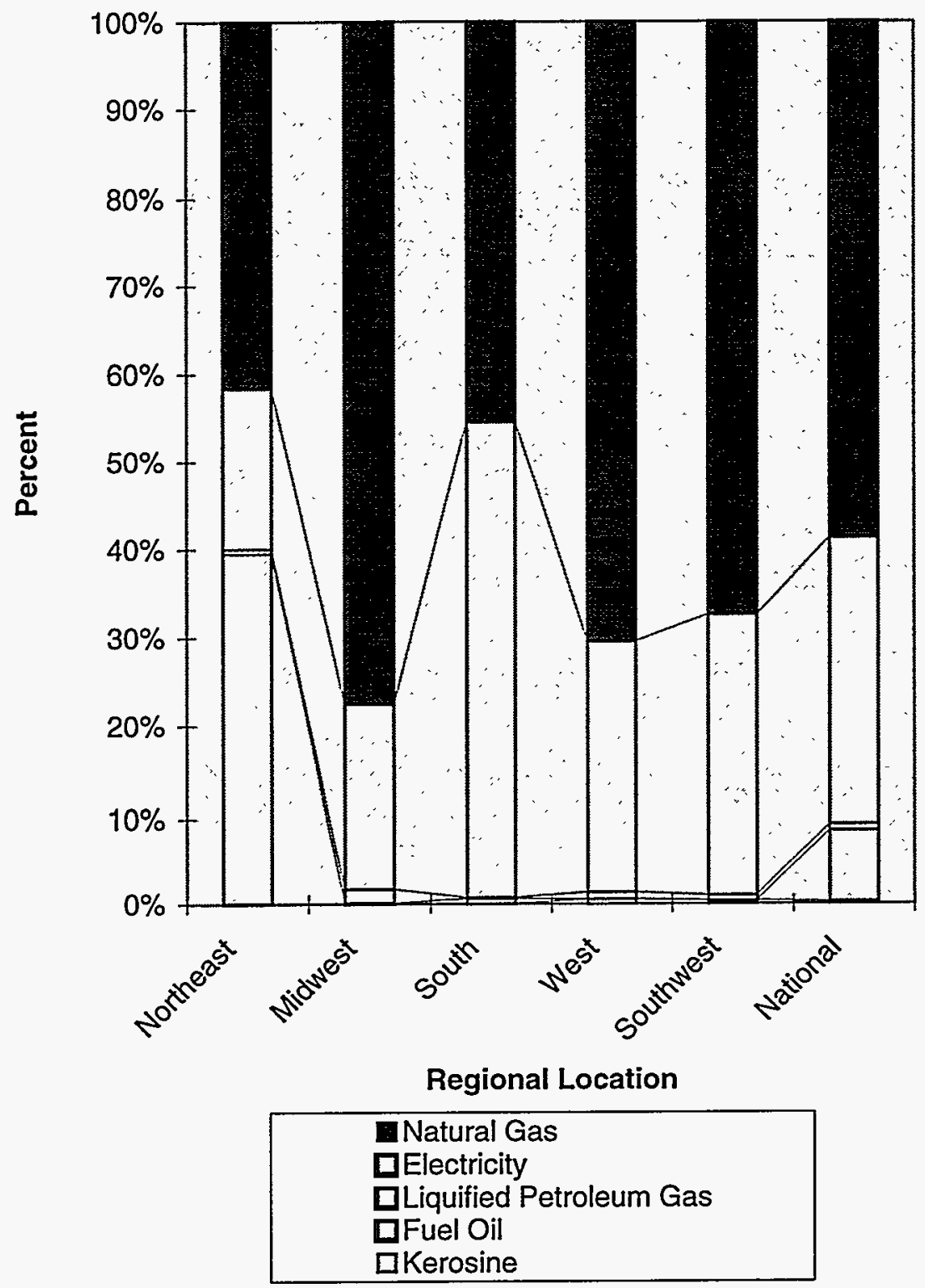

FIGURE 21990 Composition of Fuel Use: Latino Households (fuels shown from top to bottom in chart) 


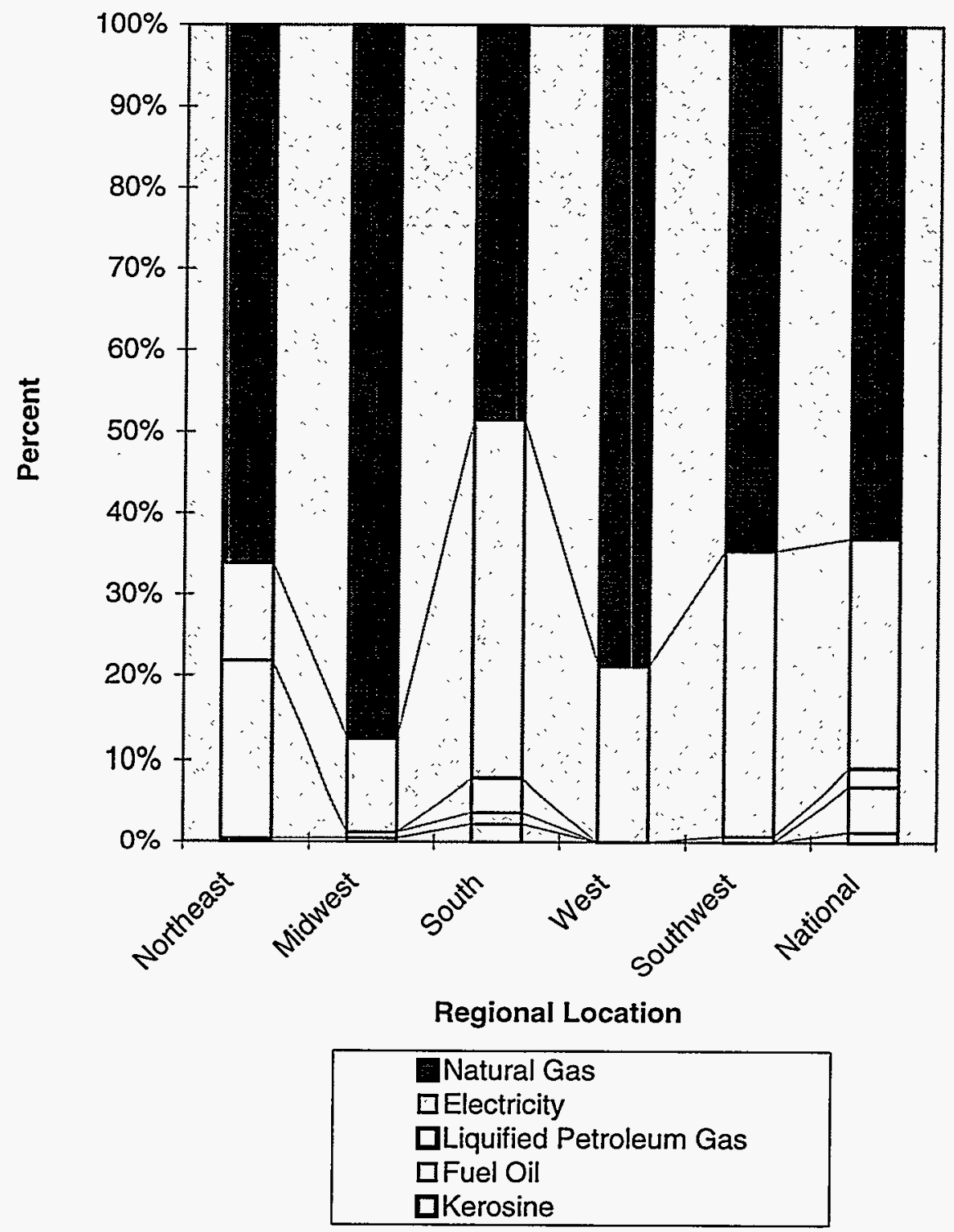

FIGURE 31990 Composition of Fuel Use: Non-Latino Black Households (fuels shown from top to bottom in chart) 
For non-Latino whites, natural gas is the major residential fuel consumed at the point of end use. ${ }^{6}$ The consumption of natural gas by non-Latino white households was most prominent in the Midwest census region. In each census region, more natural gas was consumed as a proportion of total residential energy consumption than any other fuel type, except in the south census region. In that region, electricity was the dominant residential energy source in 1990.

For Latino households, interregional changes in the composition of natural gas and electricity consumption were qualitatively similar to those for non-Latino whites. However, at both the regional and national levels, the fraction of natural gas consumption was typically larger. At the national level, natural gas represented slightly under $60 \%$ of total residential energy consumption for Latino households and slightly over 50\% of total residential energy consumption for non-Latino white households.

For non-Latino black households, the changes in the composition of natural gas and electricity consumption were qualitatively the same as for non-Latino white households. However, the magnitude of the relative difference in consumption of natural gas and electricity in non-Latino black households was dramatic. In the Midwest, natural gas represented almost $90 \%$ of total residential energy consumption in non-Latino black households, compared with $65 \%$ in non-Latino white households. Nationally, natural gas consumption constitutes about $65 \%$ of total residential energy consumption by non-Latino black households (compared with the 50\% of total consumption for non-Latino white households).

To provide a theoretical context for explaining changes in energy consumption, the energy demand model, described earlier, was estimated for Latino, black and non-Latino, nonblack households, and all households. ${ }^{7}$ The results are shown in Tables 2 through 5 . The loglikelihood function values for each of the models are listed in Tables 2 and 3. Results for each group are described below.

\subsection{LATINO ENERGY DEMAND}

The parametric estimates for the Latino and non-Latino energy demand models are shown in Tables 2 and 4. The null hypothesis that two demand systems are equivalent is overwhelmingly rejected. The estimated natural gas demand model for Latinos suggests that,

6 Clearly, electricity was the most important fuel because of its predominant share of total residential energy expenditures in 1990. For each population group, more than $50 \%$ of total residential energy expenditures were for electricity.

7 The Latino and black population categories are not mutually exclusive. Latino can be any race. 
TABLE 2 Dynamic Energy Demand Model Estimates: Latino and Non-Latino Households

\begin{tabular}{|c|c|c|c|}
\hline \multirow[b]{2}{*}{ Parameter } & \multicolumn{3}{|c|}{ Household ${ }^{\mathrm{a}}$} \\
\hline & All & Latino & Non-Latino \\
\hline \multicolumn{4}{|l|}{ Natural gas } \\
\hline $\begin{array}{l}\text { Marginal share } \\
\left(\beta_{\mathrm{ng}}\right)\end{array}$ & $\begin{array}{l}0.24 \\
(0.006)\end{array}$ & $\begin{array}{c}0.32 \\
(0.029)\end{array}$ & $\begin{array}{l}0.23 \\
(0.006)\end{array}$ \\
\hline Nondiscretionary & -10.46 & -9.94 & -10.44 \\
\hline$\left(\gamma_{n g}\right)$ & $(1.15)$ & $(5.90)$ & $(1.15)$ \\
\hline $\begin{array}{l}\text { Dynamic coefficient } \\
\left(\theta_{\mathrm{ng}}\right)\end{array}$ & $\begin{array}{l}0.83 \\
(0.007)\end{array}$ & $\begin{array}{c}0.65 \\
(0.029)\end{array}$ & $\begin{array}{c}0.84 \\
(0.007)\end{array}$ \\
\hline \multicolumn{4}{|l|}{ Electricity } \\
\hline $\begin{array}{l}\text { Marginal share } \\
\left(\beta_{\mathrm{el}}\right)\end{array}$ & $\begin{array}{c}0.56 \\
(0.006)\end{array}$ & $\begin{array}{c}0.55 \\
(0.026)\end{array}$ & $\begin{array}{l}0.57 \\
(0.006)\end{array}$ \\
\hline $\begin{array}{l}\text { Nondiscretionary } \\
\left(\gamma_{\mathrm{el}}\right)\end{array}$ & $\begin{array}{l}-6.04 \\
(0.60)\end{array}$ & $\begin{array}{l}-3.72 \\
(2.03)\end{array}$ & $\begin{array}{l}-6.41 \\
(0.65)\end{array}$ \\
\hline $\begin{array}{l}\text { Dynamic coefficient } \\
\left(\theta_{\mathrm{el}}\right)\end{array}$ & $\begin{array}{l}0.79 \\
(0.011)\end{array}$ & $\begin{array}{c}0.72 \\
(0.044)\end{array}$ & $\begin{array}{c}0.80 \\
(0.012)\end{array}$ \\
\hline \multicolumn{4}{|l|}{ Fuel oil/kerosene } \\
\hline $\begin{array}{l}\text { Marginal share } \\
\left(\beta_{\mathrm{fo}}\right)\end{array}$ & $\begin{array}{l}0.13 \\
(0.005)\end{array}$ & $\begin{array}{c}0.09 \\
(0.022)\end{array}$ & $\begin{array}{l}0.13 \\
(0.005)\end{array}$ \\
\hline $\begin{array}{l}\text { Nondiscretionary } \\
\left(\gamma_{\mathrm{fo}}\right)\end{array}$ & $\begin{array}{l}-6.58 \\
(0.62)\end{array}$ & $\begin{array}{l}-3.82 \\
(2.15)\end{array}$ & $\begin{array}{l}-6.81 \\
(0.66)\end{array}$ \\
\hline $\begin{array}{l}\text { Dynamic coefficient } \\
\left(\theta_{\mathrm{fo}}\right)\end{array}$ & $\begin{array}{l}0.74 \\
(0.006)\end{array}$ & $\begin{array}{l}0.73 \\
(0.029)\end{array}$ & $\begin{array}{l}0.74 \\
(0.007)\end{array}$ \\
\hline \multicolumn{4}{|l|}{ Liquid petroleum gas } \\
\hline $\begin{array}{l}\text { Marginal share } \\
\left(\beta_{\mathrm{lp}}\right)\end{array}$ & $\begin{array}{c}0.07 \\
(0.003)\end{array}$ & $\begin{array}{c}0.04 \\
(0.007)\end{array}$ & $\begin{array}{c}0.07 \\
(0.003)\end{array}$ \\
\hline $\begin{array}{l}\text { Nondiscretionary } \\
\left(\gamma_{l p}\right)\end{array}$ & $\begin{array}{l}-1.96 \\
(0.20)\end{array}$ & $\begin{array}{l}-0.76 \\
(0.33)\end{array}$ & $\begin{array}{l}-2.04 \\
(0.21)\end{array}$ \\
\hline $\begin{array}{l}\text { Dynamic coefficient } \\
\left(\theta_{\mathrm{lp}}\right)\end{array}$ & $\begin{array}{l}0.77 \\
(0.007)\end{array}$ & $\begin{array}{l}0.89 \\
(0.021)\end{array}$ & $\begin{array}{l}0.76 \\
(0.007)\end{array}$ \\
\hline Log-likelihood function & $-208,071$ & $-11,698$ & $-196,071$ \\
\hline
\end{tabular}

a Standard errors are shown in parentheses. 
TABLE 3 Dynamic Energy Demand Model Estimates: Black and Non-Black Households

\begin{tabular}{|c|c|c|c|}
\hline \multirow[b]{2}{*}{ Parameter } & \multicolumn{3}{|c|}{ Household $^{\mathrm{a}}$} \\
\hline & All & Black & Non-Black \\
\hline \multicolumn{4}{|l|}{ Natural gas } \\
\hline Marginal share & 0.24 & 0.39 & 0.21 \\
\hline$\left(\beta_{\text {ng }}\right)$ & $(0.006)$ & $(0.023)$ & $(0.006)$ \\
\hline Nondiscretionary & -10.46 & -22.01 & -8.98 \\
\hline$\left(\gamma_{\mathrm{ng}}\right)$ & $(1.15)$ & $(6.51)$ & $(1.08)$ \\
\hline Dynamic coefficient & 0.83 & 0.77 & 0.84 \\
\hline$\left(\theta_{\mathrm{ng}}\right)$ & $(0.007)$ & $(0.031)$ & $(0.007)$ \\
\hline \multicolumn{4}{|l|}{ Electricity } \\
\hline Marginal share & 0.56 & 0.45 & 0.58 \\
\hline$\left(\beta_{\mathrm{el}}\right)$ & $(0.006)$ & $(0.020)$ & $(0.007)$ \\
\hline Nondiscretionary & -6.04 & -6.60 & -5.87 \\
\hline$\left(\gamma_{\mathrm{el}}\right)$ & $(0.60)$ & $(1.39)$ & $(0.66)$ \\
\hline Dynamic coefficient & 0.79 & 0.77 & 0.79 \\
\hline$\left(\theta_{\mathrm{el}}\right)$ & $(0.011)$ & $(0.032)$ & $(0.012)$ \\
\hline \multicolumn{4}{|l|}{ Fuel oil/kerosene } \\
\hline Marginal share & 0.13 & 0.13 & 0.13 \\
\hline$\left(\beta_{\mathrm{fo}}\right)$ & $(0.005)$ & $(0.014)$ & $(0.005)$ \\
\hline Nondiscretionary & -6.58 & -10.63 & -6.35 \\
\hline$\left(\gamma_{\mathrm{fo}}\right)$ & $(0.62)$ & $(2.18)$ & $(0.63)$ \\
\hline Dynamic coefficient & 0.74 & 0.63 & 0.75 \\
\hline$\left(\theta_{\mathrm{fo}}\right)$ & $(0.006)$ & $(0.020)$ & $(0.007)$ \\
\hline \multicolumn{4}{|l|}{ Liquid petroleum gas } \\
\hline Marginal share & 0.07 & 0.03 & 0.08 \\
\hline$\left(\beta_{\mathrm{lp}}\right)$ & $(0.003)$ & $(0.008)$ & $(0.004)$ \\
\hline Nondiscretionary & -1.96 & -0.87 & -2.09 \\
\hline$\left(\gamma_{\mathrm{lp}}\right)$ & $(0.20)$ & $(0.49)$ & $(0.22)$ \\
\hline Dynamic coefficient & 0.77 & 0.82 & 0.76 \\
\hline$\left(\theta_{\mathrm{lp}}\right)$ & $(0.007)$ & $(0.021)$ & $(0.008)$ \\
\hline Log-likelihood function & $-208,071$ & $-23,566$ & $-184,118$ \\
\hline
\end{tabular}

a Standard errors are shown in parentheses. 
TABLE 4 Energy Expenditure Model Estimates: Latino and Non-Latino Households

\begin{tabular}{|c|c|c|c|}
\hline \multirow[b]{2}{*}{ Parameter } & \multicolumn{3}{|c|}{ Household ${ }^{\mathrm{a}}$} \\
\hline & All & Latino & Non-Latino \\
\hline Household income & $\begin{array}{l}0.0066 \\
(0.00026)\end{array}$ & $\begin{array}{c}0.0092 \\
(0.0026)\end{array}$ & $\begin{array}{l}0.0063 \\
(0.00025)\end{array}$ \\
\hline Household members & $\begin{array}{r}105.72 \\
(3.72)\end{array}$ & $\begin{array}{c}64.42 \\
(12.65)\end{array}$ & $\begin{array}{l}113.03 \\
(3.95)\end{array}$ \\
\hline $\begin{array}{l}\text { Cooling degree days (CDD) } \\
\left(65^{\circ} \mathrm{F} \text { base }\right)\end{array}$ & $\begin{array}{c}0.080 \\
(0.011)\end{array}$ & $\begin{array}{r}0.1017 \\
(0.031)\end{array}$ & $\begin{array}{c}0.075 \\
(0.012)\end{array}$ \\
\hline $\begin{array}{l}\text { Heating degree days (HDD) } \\
\left(65^{\circ} \mathrm{F} \text { base }\right)\end{array}$ & $\begin{array}{c}0.054 \\
(0.004)\end{array}$ & $\begin{array}{l}0.087 \\
(0.0134)\end{array}$ & $\begin{array}{c}0.048 \\
(0.004)\end{array}$ \\
\hline $\mathrm{CDD} \times \mathrm{HDD}$ & $\begin{array}{r}3.44 \times 10^{-5} \\
\left(3.64 \times 10^{-6}\right)\end{array}$ & $\begin{array}{r}1.68 \times 10^{-5} \\
\left(1.41 \times 10^{-5}\right)\end{array}$ & $\begin{array}{r}3.40 \times 10^{-5} \\
\left(3.70 \times 10^{-6}\right)\end{array}$ \\
\hline $\begin{array}{l}\text { Consumer price index urban } \\
(1979=1)\end{array}$ & $\begin{array}{l}164.22 \\
(17.37)\end{array}$ & $\begin{array}{c}42.17 \\
(58.08)\end{array}$ & $\begin{array}{l}184.09 \\
(18.33)\end{array}$ \\
\hline Central city location & $\begin{array}{l}-67.18 \\
(13.40)\end{array}$ & $\begin{array}{l}-14.71 \\
(49.21)\end{array}$ & $\begin{array}{l}-63.04 \\
(13.96)\end{array}$ \\
\hline Non-metropolitan location & $\begin{array}{r}-106.92 \\
(14.44) \\
\end{array}$ & $\begin{array}{l}-88.80 \\
(73.61)\end{array}$ & $\begin{array}{r}-109.96 \\
(14.76) \\
\end{array}$ \\
\hline
\end{tabular}

a Standard errors are shown in parentheses.

under a regime of higher natural gas prices, Latinos natural gas expenditures are likely to increase at a slower rate than those for non-Latinos. The larger expenditure-share parameter and the smaller dynamic-adjustment parameter reinforce this finding. 8

The electricity demand model reveals that the nondiscretionary demand parameter in Latino households is more than one and half times greater than in non-Latino households.

8 The nondiscretionary demand for natural gas will play little or no role because of the closeness of its value for both Latinos and non-Latinos. Also, the value of the lagged consumption of natural gas is important. For different population groups, if the values are very different, historical patterns of natural gas expenditures could be very different. 
Consequently, electricity expenditures (certainly in the long run) are expected to increase at a faster rate in Latino households than in non-Latino white households.

under a regime of higher natural gas prices, Latinos natural gas expenditures are likely to increase at a slower rate than those for non-Latinos. The larger expenditure-share parameter and the smaller dynamic-adjustment parameter reinforce this finding. ${ }^{9}$

The electricity demand model reveals that the nondiscretionary demand parameter in Latino households is more than one and half times greater than in non-Latino households. Consequently, electricity expenditures (certainly in the long run) are expected to increase at a faster rate in Latino households than in non-Latino white households.

The relative changes in expenditures associated with electricity and natural gas implied by the model seem to be confirmed by the expenditure data reviewed earlier. These data indicate that real electricity expenditures in relation to nonelectric energy expenditures increase at a faster rate in Latino households than in non-Latino households. ${ }^{10}$

\subsection{BLACK ENERGY DEMAND}

The parametric estimates for the black and nonblack energy demand models are shown in Tables 3 and 5 . Once again, the null hypothesis is overwhelmingly rejected.

As in the case of Latinos, the estimated natural gas demand model for black households implies that, under a regime of higher natural gas prices, expenditures by black households for natural gas are likely to increase at a slower rate than those for nonblack households. The larger expenditure-share parameter in black households and the smaller nondiscretionary natural-gasdemand parameter are likely to reinforce this result.

For the electricity model, the smaller marginal expenditure-share parameter in black households implies that electricity expenditures in black households are likely to increase at a relatively faster rate, whereas the historically lower level of electricity consumption in black households will prevent a substantial overall increase.

${ }^{9}$ The nondiscretionary demand for natural gas will play little or no role because of the closeness of its value for both Latinos and non-Latinos. Also, the value of the lagged consumption of natural gas is important. For different population groups, if the values are very different, historical patterns of natural gas expenditures could be very different.

10 This finding, of course, assumes that electricity and natural gas prices are increasing at about the same rate and that nondiscretionary energy expenditures remain about the same, leaving only price changes to influence expenditures. 
TABLE 5 Energy Expenditure Model Estimates: Black and Non-Black Households

\begin{tabular}{lccc}
\hline & \multicolumn{3}{c}{ Household ${ }^{\mathrm{a}}$} \\
\cline { 2 - 4 } \multicolumn{1}{c}{ Parameter } & All & Black & Non-Black \\
\cline { 2 - 4 } Household income & 0.0066 & 0.0070 & 0.0067 \\
& $(0.00026)$ & $(0.0011)$ & $(0.00027)$ \\
Household members & 105.72 & 115.09 & 102.50 \\
& $(3.72)$ & $(9.58)$ & $(4.18)$ \\
Cooling degree days (CDD) & 0.080 & 0.057 & 0.087 \\
$\left(65^{\circ} \mathrm{F}\right.$ base) & $(0.011)$ & $(0.035)$ & $(0.012)$ \\
& & & \\
Heating degree days (HDD) & 0.054 & 0.087 & 0.053 \\
$\left(65^{\circ} \mathrm{F}\right.$ base) & $(0.004)$ & $(0.0155)$ & $(0.004)$ \\
CDD $\times$ HDD & & & \\
& $3.44 \times 10^{-5}$ & $2.86 \times 10^{-5}$ & $3.24 \times 10^{-5}$ \\
& $\left(3.64 \times 10^{-6}\right)$ & $\left(1.30 \times 10^{-5}\right)$ & $\left(3.80 \times 10^{-6}\right)$ \\
Consumer price index urban & 164.22 & 138.00 & 166.02 \\
$(1979=1)$ & $(17.37)$ & $(55.48)$ & $(17.97)$ \\
Central city location & & & \\
& -67.18 & -26.92 & -92.22 \\
Non-metropolitan location & $(13.40)$ & $(49.21)$ & $(14.28)$ \\
& -106.92 & -159.22 & -96.99 \\
& $(14.44)$ & $(53.36)$ & $(14.71)$ \\
\hline
\end{tabular}

a Standard errors are shown in parentheses. 


\section{POLICY IMPLICATIONS OF DIFFERENCES IN LATINO AND NON-LATINO ENERGY DEMAND}

The effects of energy policies and programs on the relative prices of residential fuel sources will affect the economic welfare of Latino, non-Latino white, and non-Latino black groups differently. Whether price changes occur in response to macroeconomic or market-driven dynamics, or to federal price or state public utility policies, the economic welfare implications of policies and programs that affect the service price of residential energy sources can be estimated by the cost function given in Equation (6). Specifically, the relative impact of energy policies and programs at the household level are determined by the relative magnitudes of the marginal share, nondiscretionary demand, dynamic adjustment coefficient parameters, and levels of fuel consumption evident among these diverse households.

For Latino and non-Latino population groups, the comparative economic welfare impacts of changing energy prices are not clear-cut. The economic welfare changes implied by the estimated marginal share parameters are often offset by the implied changes associated with the estimated nondiscretionary demand parameter and differences in the patterns of energy use.

Each policy scenario will have to be evaluated on its own merits, using the parameters in the model as a frame of reference. Both the magnitude and the timing of energy price changes will have an effect on the comparative economic consequences of energy policy. It is clear, however, that the intragroup distribution of a policy's impact for Latino households will differ from that for non-Latino black and non-Latino white households. The impact of these differences has consequences not only for such compensatory energy policies as the national Low-Income Household Energy Assistance Program (LIHEAP) and such state utility rate schemes as lifeline and declining block rate structures, but also for a variety of income transfer programs designed to sustain and expand the economic welfare of these households. Low income and subsidized housing programs, Aid to Families with Dependent Children, Supplemental Security Income Programs under the Social Security Administration, and other income maintenance programs are designed to address poverty caused by a combination of household income stresses, including energy price increases.

The next step is to apply the model to household energy data to simulate how potential policy scenarios are likely to affect different population groups in terms of both overall economic impact and distributive consequences. The work of Cook and Scioli (1971) on policy impact assessment is potentially strengthened by the application of the household energy demandconsumption-expenditure model. They recommend a reciprocal approach to impact assessment: groups and institutions are affected by events; those events mobilize groups and institutions to develop new policies or alter existing policies; resultant policy development and implementation stimulate more economic, social, and political events; these events generate more impacts for groups and institutions. Thus, the energy demand model, combined with policy assessment models, can provide higher levels of validity and reliability in assessing energy policy impacts. Once these impacts are evaluated, the results can help policymakers to anticipate how various 
demographic and socioeconomic groups, affected differently by energy events and policies, are likely to alter their behavior in terms of household energy consumption and expenditure. The result is an approach to impact assessment that is both highly empirical in the inputs it generates from data sources and analyses and anticipatory of economic and socioeconomic impacts, the assessment of which helps policymakers to anticipate and respond creatively to all groups affected by such events and policies. 


\section{CONCLUSIONS}

This report discusses energy demand and expenditure patterns for Latino and non-Latino households in the United States as a case study of residential energy consumption across different population groups in a country.

As expected, the data analyzed indicated that the patterns of energy use and expenditures among Latino, non-Latino black, and non-Latino white households in the United States generally differ. The analyzed energy sources included electricity, natural gas, fuel oil, and LPG. The literature search confirmed that residential energy demand by fuel type for Latinos has not been explained by economic and noneconomic factors in any statistical model in the public domain.

The linear expenditure system model developed by Stone and Geary was selected as the basis to explain the fuel consumption of and expenditures for Latino and other population groups (including non-Latino black, non-Latino white, and all households) in the United States. This model estimates energy consumption of and expenditures for electricity, natural gas, fuel oil, and LPG by various households at the national level. Significant variations in the consumption patterns of these fuels by Latino and non-Latino households were noted, and the policy implications of the differential energy demand of Latino and non-Latino households were discussed.

As in the United States, residential energy cost is an important part of the household budget in many countries and could vary significantly across different population groups.

The model methodology and results of this research should be useful to energy policymakers in government and industry, researchers, and academicians who are concerned with economic and energy issues related to various population groups. 


\section{REFERENCES}

Baxter, L., et al., 1987, "Determinants of Household Energy Efficiency and Demand," in Energy Efficiency: Perspectives on Individual Behavior, W. Kempton and M. Neiman, eds., American Council for an Energy-Efficient Economy, Washington, D.C.

Blattenberger, G.R., L.D. Taylor, and R.K. Rennback, 1983, "Natural Gas Availability and the Residential Demand for Energy," The Energy Journal 4(1):23-45.

Bohi, D.R., 1981, “Analyzing Demand Behavior — A Study of Energy Elasticities,” published for Resources for the Future, John Hopkins Press, Baltimore, Md.

Chapa, J., and R.R. Valencia, 1993, "Latino Population Growth, Demographic Characteristics, and Educational Stagnation: An Examination of Recent Trends," Hispanic Journal of Behavioral Sciences 15(2):165-187.

Cook, T., and F. Scioli, 1971, Policy Impact Dynamics, Lexington Books, Lexington, Mass.

Cowing, T.G., and D.L. McFadden, 1984, Microeconomic Modeling and Policy Analysis Studies in Residential Energy Demand, Academic Press, Orlando, Fla.

DOE: See U.S. Department of Energy.

DOE, 1982a, Residential Energy Consumption Survey: Consumption and Expenditures, April 1980 through March 1981, Part 1: National Data, DOE/EIA-0321/1 (80), No. 061-003-00278-1, Energy Information Administration, U.S. Government Printing Office, Washington, D.C., Sept.

DOE, 1982b, Residential Energy Consumption Survey: Housing Characteristics, Annualized Consumption and Expenditures, 1980-81, No. PB-83-199554, public-use data tape, Energy Information Administration, National Technical Information Service, Springfield, Va.

DOE, 1983a, Residential Energy Consumption Survey 1981-82, public-use data tape, Energy Information Administration, National Technical Information Service, Springfield, Va.

DOE, 1983b, Residential Energy Consumption Survey 1981-82, DOE/EIA-0321/1(81), Energy Information Administration, Washington, D.C.

DOE, 1984a, Model Documentation: Household Model of Energy, Energy Information Administration Report DOE/EIA-0409, Washington, D.C. 
DOE, 1984b, Residential Energy Consumption Survey: Consumption and Expenditures, April 1982 through March 1983, Part 1: National Data, DOE/EIA-0321/1 (82), No. 061-003-00411-3, Energy Information Administration, U.S. Government Printing Office Stock, Washington, D.C., Nov.

DOE, 1985, Residential Energy Consumption Survey: 1982 and Residential Transportation Energy Consumption Survey, 1983, No. PB-85-221760; public-use data tape, Energy Information Administration, National Technical Information Service, Springfield, Va.

DOE, 1987a, Residential Energy Consumption Survey: Consumption and Expenditures, April 1984 through March 1985, Part 1: National Data, DOE/ELA-0321/1 (84), No. 061-003-00519-5, Energy Information Administration Report, U.S. Government Printing Office, Washington, D.C. March.

DOE, 1987b, Residential Energy Consumption Survey: 1984 and Residential Transportation Energy Consumption Survey, 1985, No. PB-87-186540, public-use data tape, Energy Information Administration, National Technical Information Service, Springfield, Va.

DOE, 1989a, Residential Energy Consumption Survey: 1987 and Residential Transportation Energy Consumption Survey, 1988, No. PB-90-501461, public-use data tape, Energy Information Administration, National Technical Information Service, Springfield, Va.

DOE, 1989b, Household Energy Consumption and Expenditures 1987, Part 1: National Data, DOE/EIA-0321/1 (87), No. 061-003-00635-3, Energy Information Administration, U.S. Government Printing Office, Washington, D.C., Oct.

DOE, 1993a, Residential Energy Consumption Survey, 1990, No. PB-93504942, public-use data tape, Energy Information Administration, National Technical Information Service, Springfield, Va.

DOE, 1993b, Household Energy Consumption and Expenditures 1990, DOE/EIA-0321 (90), Energy Information Administration, Washington, D.C.

DOE, 1993c, Household Energy Consumption and Expenditures 1990 - Supplement: Regional, DOE/EIA-0321 (90)/S, Energy Information Administration, Washington, D.C., U.S. Government Printing Office, Feb.

Dubin, J.A., 1985, Consumer Durable Choice and the Demand for Electricity, Elsevier Science Publishers, Amsterdam, the Netherlands. 
Dubin, J.A., and D.L. McFadden, 1984, "An Econometric Analysis of Residential Electric Appliance Holdings and Consumption," Econometrica 52(2):345-362.

Electric Power Research Institute, 1982, Price Elasticities of Demand for Energy - Evaluating the Estimates, EA-2612, Palo Alto, Calif.

Geary, R.C., 1950-51, "A Note on 'A Constant Utility Index of the Cost of Living," Review of Economic Studies 18:65-66.

Hamblin, D.M., et al., 1986, The ORNL Residential Reference House Demand Model (ORNLRRHED), Volume 3: Technical Description, ORNL/CON-177/V3, Oak Ridge National Laboratory, Oak Ridge, Tenn.

Hsing, Y., 1994, "Estimation of Residential Demand for Electricity with the Cross-Sectionally Correlated and Time-Wise Autoregressive Model," Resource and Energy Economics 16(3): 255263.

Khazzoom, J.D., 1986, An Econometric Model Integrating Conservation Measures in the Residential Demand for Electricity, JAI Press, Inc., Greenwich, Conn.

Lee, R.S., and N. Singh, 1994, "Patterns in Residential Gas and Electricity Consumption: An Econometric Analysis," Journal of Business \& Economic Statistics 12(2): 233-241.

Lutzenhiser, L., 1992, "A Cultural Model of Household Energy Consumption," Energy 17(1):47-60.

Lutzenhiser, L., 1993, "Social and Behavioral Aspects of Energy Use," Annual Review of Energy and the Environment 18:247-289.

Morrissey, A., 1984, An Econometric Analysis of Home Energy Expenditures and Need, Ph.D. dissertation, University of Notre Dame, South Bend, Ind.

Perez, S.M., and D.D.L.R. Salazar, 1993, "Economic, Labor Force, and Social Implications of Latino Educational and Population Trends," Hispanic Journal of Behavioral Sciences 15(2):188-229, May.

Pollak, R.A., 1970, "Habit Formation and Dynamic Demand Functions," Journal of Political Economy 78:745-763.

Poyer, D.A., and M. Williams, 1993, "Residential Energy Demand: Additional Empirical Evidence by Minority Household Type," Energy Economics 15(2): 93-100. 
Stone, R., 1954, "Linear Expenditure System and Demand Analysis: An Application to the Pattern of British Demand," Economic Journal 64:511-527.

U.S. Department of Commerce, Bureau of the Census, 1991, U.S. Department of Commerce News, press release CB91-216, Washington, D.C. 
